\title{
PENGEMBANGAN MULTIMEDIA PEMBELAJARAN INTERAKTIF PADA MATA PELAJARAN ILMU PENGETAHUAN ALAM UNTUK SISWA KELAS VIII SMP
}

\section{THE DEVELOPMENT OF INTERACTIVE LEARNING MULTIMEDIA IN SCIENCE FOR EIGHTH GRADE STUDENT IN JUNIOR HIGH SCHOOL}

\author{
Achmad Darojat \\ Universitas Negeri Malang \\ Email: ozat_melodicboys@yahoo.com
}

\begin{abstract}
Abstrak: Penelitian ini bertujuan menghasilkan multimedia pembelajaran yang valid, dalam pelajaran ilmu pengetahuan alam di kelas VIII Sekolah Menengah Pertama. Penelitian ini menggunakan rancangan penelitian pengembangan dengan metode analisis, desain, pengembangan, penerapan, dan evaluasi. Hasil penelitian menunjukkan bahwa multimedia pembelajaran valid dan layak untuk digunakan dalam pembelajaran Ilmu pengetahuan alam kelas VIII SMP.
\end{abstract}

Kata-kata kunci: Pengembangan, Multimedia Pembelajaran Interaktif, IPA

\begin{abstract}
This research is purposed to produce the multimedia learning which has been validated for eighth grade student of 13 Junior High School Malang. This study design was used to study the development of methods of analysis, design, development, implementation, and evaluation . The results showed that the learning multimedia valid and feasible for use in teaching natural sciences eighth grade student of Junior High School.
\end{abstract}

Key words: Development, Interactive Learning Multimedia, Science 
Dalam perkembangan teknologi terdapat beragam bentuk dan jenis produk untuk pendidikan. Salah satunya adalah media pembelajaran. Miarso (2005:458) menyimpulkan "kegunaan media dalam pembelajaran mampu memberikan rangsangan yang bervariasi kepada otak kita, sehingga otak kita dapat berfungsi secara optimal". Sebagai salah satu implikasi dalam pembelajaran ialah kedua belahan otak perlu dirangsang bergantian dengan rangsangan audio dan visual.

Dalam dunia pendidikan, multimedia pembelajaran interaktif memiliki potensi yang besar untuk meningkatkan kualitas pembelajaran. Khususnya dalam pembelajaran mata pelajaran Ilmu Pengetahuan Alam. Banyak hal abstrak atau imajinatif yang sulit dipikirkan peserta didik dapat di presentasikan melalui simulasi multimedia pembelajaran interaktif. Hal ini tentu saja akan lebih menyederhanakan jalan pikiran peserta didik dalam memahaminya. Dengan demikian pengembangan proses pembelajaran Ilmu Pengetahuan Alam dapat dilakukan guru dengan memberdayakan multimedia pembelajaran interaktif. Penggunaan multimedia pembelajaran interaktif untuk keperluan pendidikan yang semakin meluas terutama di negara-negara maju, merupakan fakta yang menunjukkan bahwa dengan media ini memang dimungkinkan diselenggarakannya proses belajar mengajar yang lebih efektif. Hal itu terjadi karena dengan sifat dan karakteristik multimedia pembelajaran interaktif yang cukup khas, diharapkan bisa digunakan sebagai media pembelajaran sebagaimana media lain telah dipergunakan sebelumnya seperti radio, televisi, CD-ROM Interaktif dan lain-lain. Sebagai media tutorial dalam pembelajaran, multimedia pembelajaran interaktif memungkinkan berlangsungnya proses belajar secara individual dan klasikal.

Sistem multimedia pembelajaran interaktif merupakan bentuk implementasi pembelajaran yang memanfaatkan teknologi dan tidak dibatasi oleh ruang dan waktu. Akan tetapi, multimedia pembelajaran interaktif dapat juga dilaksanakan sebagai alternative belajar. Karena terkadang, peserta didik berhalangan mengikuti pembelajaran secara tatap muka. Multimedia pembelajaran interaktif berfungsi sebagai option (pilihan) bagi peserta didik. Selain itu bentuk media yang akan digunakan dalam proses belajar mengajar harus diperhatikan pemanfaatannya bagi peserta didik.

Melihat kondisi di atas, SMP Negeri 13 Malang merupakan salah satu sekolah yang sudah menyediakan fasilitas-fasilitas Laboratorium komputer, Laboratorium Bahasa, LCD projector disetiap kelasnya, dan fasilitas yang lain untuk mendukung proses belajar mengajar di sekolah tersebut. Pada Laboratorium komputer terdapat 20 unit komputer, dan terdapat jaringan internet. Jumlah peserta didik setiap kelas 35 peserta didik, sehingga sangat membantu peserta didik untuk menerapkan pembelajaran berbantuan komputer (PBK), juga terdapat LCD projector di dalam kelas sehingga memungkinkan terlaksananya pembelajaran klasikal yang sangat efektif.

Metode pengajaran yang digunakan juga sudah bervariasi dan membangun keaktifan serta kreativitas peserta didik. Guru mengajar sesuai dengan mata pelajaran yang dikuasai. Berdasarkan uraian di atas peneliti tertarik untuk mengadakan penelitian dengan judul "Pengembangan Multimedia Pembelajaran Interaktif Pada Mata Pelajaran Ilmu Pengetahuan Alam Untuk Meningkatkan Hasil Belajar Siswa Kelas VIII SMP"

\section{METODE}

Pengembangan media ini memerlukan kerangka model tertentu sebagai kerangka acuan berfikir dan melangkah. Dalam mengembangkan sebuah media, hendaknya ditentukan terlebih dahulu prosedur yang akan dilakukan. Pengembang merujuk pada langkah-langkah yang digambarkan dalam bentuk flow chart oleh Lee \& Owens (2004 : 22). Alasan pengembang memilih Model Pengembangan Lee \& Owens karena dalam sistematika pengembangan Model Lee \& Owens terdapat lima tahap dalam 
mengembangkan multimedia pembelajaran, yaitu: (1) Analisis (Analysis), (2) Desain (Design), (3) Pengembangan (Development), (4) Penerapan (Implementation), dan (5) Evaluasi (Evaluation). Di dalam proses pengembangan multimedia pembelajaran dibutuhkan beberapa proses, diantaranya : (1) Tahap Pra Produksi, (2) Tahap Produksi, dan (3) Tahap Pasca Produksi. Ketiga proses ini terdapat dalam Model Pengembangan Lee \& Owens (dalam Lee \& Owens, 2004 : 24). Peneliti sendiri akan melakukan penelitian di SMPN 13 Malang. Dalam tahap menganalisis kebutuhan, pengembang melakukan observasi di SMPN 13 Malang Malang dan melakukan pencarian melalui internet, kemudian merumuskan tujuan yang akan dicapai. Setelah tujuan jelas, kita mengetahui kemampuan dan keterampilan apa yang diharapkan dapat dilakukan siswa, selanjutnya kita harus menentukan cara supaya siswa memiliki kemampuan dan keterampilan tersebut. Bahan pelajaran apa yang harus dipelajari atau pengalaman apa yang harus dilakukan siswa supaya tujuan pembelajaran dapat tercapai. Untuk alat evaluasi, pengembang menggunakan instrumen angket, dan post test. Kemudian langkah selanjutnya adalah menyusun storyboard, dilanjutkan dengan produksi multimedia pembelajaran Ilmu pengetahuan alam kelas VIII, dan membuat modul pemanfaatan multimedia pembelajaran. Apabila langkah diatas sudah dilakukan, kemudian dilanjutkan pada proses validasi kepada ahli media, ahli materi, dan langsung terjun kelapangan untuk melakukan ujicoba lapangan sekaligus tes evaluasi kepada siswa SMPN 13 Malang kelas VIII. Setelah langkah tersebut selesai dilakukan, pengembang melakukan revisi terhadap multimedia pembelajaran apabila diperlukan.

\section{HASIL DAN PEMBAHASAN}

Paparan data hasil validasi dan uji coba

Penyajian data validasi berupa hasil jawaban ahli media, ahli materi dan uji coba audiens/ siswa. Rumus untuk mengolah data ini menggunakan rumus yang telah ditetapkan dan acuan interpretasi data disesuaikan berdasarkan kriteria yang telah ditetapkan (Arikunto, 2002). Setelah dilakukan validasi ahli media berjumlah 1 orang, ditentukan hasil berupa data dari instrumen angket tentang multimedia pembelajaran Ilmu pengetahuan alam bab sistem tata surya, didapatkan hasil $88,4 \%$, berdasarkan kriteria yang ditetapkan hasil validasi tersebut tergolong dalam persentase 85-100, maka dapat diinterpretasikan bahwa multimedia pembelajaran Ilmu pengetahuan alam sub bab sistem tata surya yang dikembangkan termasuk dalam criteria Valid atau kualifikasi Layak digunakan untuk proses pembelajaran, dan pada validasi ahli materi berjumlah 1 orang, ditentukan hasil berupa data dari instrumen angket tentang multimedia pembelajaran Ilmu pengetahuan alam sub bab sistem tata surya. Analisis data hasil validasi ahli materi diperoleh 95\%, berdasarkan kriteria yang ditetapkan hasil validasi tersebut tergolong dalam persentase 85-100, maka dapat diinterpretasikan bahwa multimedia pembelajaran Ilmu pengetahuan alam bab sistem tata surya yang dikembangkan termasuk dalam kriteria Valid atau kualifikasi Layak digunakan untuk proses pembelajaran. Pada uji coba audiens/ siswa satu lawan satu berjumlah 2 orang, detemukan hasil $96 \%$, berdasarkan kriteria yang ditetapkan hasil validasi tersebut tergolong dalam persentase 85-100, maka dapat diinterpretasikan bahwa multimedia pembelajaran Ilmu pengetahuan alam bab sistem tata surya yang dikembangkan termasuk dalam kriteria Valid atau kualifikasi Layak digunakan untuk proses pembelajaran. Selanjutnya pada uji coba audiens/ siswa kelompok kecil berjumlah 10 orang, diperoleh hasil 93\%, berdasarkan kriteria yang ditetapkan hasil validasi tersebut tergolong dalam persentase 85-100, maka dapat diinterpretasikan bahwa multimedia pembelajaran Ilmu pengetahuan alam sub bab sistem tata surya yang dikembangkan termasuk dalam kriteria Valid atau kualifikasi Layak digunakan untuk proses pembelajaran. Setelah dilakukan validasi Ahli Media, Ahli Materi, dan uji coba audiens/ siswa hasilnya 
multimedia pembelajaran Ilmu pengetahuan alam sub bab sistem tata surya yang dikembangkan termasuk dalam kriteria Valid atau kualifikasi Layak digunakan untuk proses pembelajaran. Untuk tes hasil belajar yang diberikan pada saat uji coba lapangan, diperoleh hasil bahwa subyek 1 sampai dengan subyek 35 mendapatkan skor mencapai KKM atau diatas skor 75 . Dengan demikian dapat dijelaskan bahwa 35 siswa yang telah menyelesaikan tes hasil belajar pada saat uji coba lapangan mendapatkan skor Mencapai KKM (Kriteria Ketuntasan Minimal). Berdasarkan kriteria yang ditetapkan hasil evaluasi tersebut, maka dapat diinterpretasikan bahwa pembelajaran Ilmu pengetahuan alam menggunakan multimedia pembelajaran dikategorikan efektif.

\section{Revisi multimedia pembelajaran}

Revisi produk pengembangan merupakan kesimpulan yang diambil dari hasil analisis angket baik dari ahli media, ahli materi, maupun audiens/ siswa tentang produk yang divalidasikan sebagai dasar untuk revisi. Berdasarkan angket yang diberikan kepada ahli media, diperoleh tanggapan bahwa multimedia pembelajaran yang baik memiliki fungsi fasilitas yang maksimal, contohnya seperti font huruf yang mudah untuk dibaca, background video yang tepat, dan gambar video yang menarik, selain itu sebaiknya cover DVD multimedia pembelajaran di cetak menggunakan cetak laser bukan cetak inkjet. Sedangkan pendapat menurut ahli materi diperoleh tanggapan bahwa multimedia pembelajaran cukup menarik bagi siswa, dan bisa dikembangkan lagi untuk materi-materi yang lain, selain itu konten multimedia sebaiknya juga diberikan resume tentang materi yang telah dibahas. Selanjutnya pendapat menurut audiens diperoleh tanggapan bahwa multimedia pembelajaran dapat menambah semangat belajar dan membuat suasana belajar menjadi nyaman, selain itu audiens berpendapat, multimedia pembelajaran sebaiknya lebih sering diberikan supaya suasana belajar menjadi menyenangkan dan siswa tidak jenuh.
Saran bagi siswa, guru, dan sekolah

Saran bagi siswa dalam menggunakan multimedia pembelajaran Ilmu pengetahuan alam, sebaiknya membaca dan mempelajari dengan baik petunjuk pemanfaatan sebelum menggunakan multimedia pembelajaran. Siswa juga disarankan untuk mempelajari dengan baik materi tentang sistem tata surya supaya lebih memahami isi multimedia pembelajaran. Sedangkan Saran bagi guru dalam menggunakan multimedia pembelajaran Ilmu pengetahuan alam, multimedia pembelajaran Ilmu pengetahuan alam dijadikan sebagai media pembelajaran yang membantu guru dalam proses belajar mengajar, selain itu ada beberapa hal yang harus diperhatikan guru untuk kelancaran kegiatan belajar mengajar dengan multimedia pembelajaran, diantaranya guru harus mempelajari petunjuk atau penyerta untuk guru beserta materi yang terdapat di dalamnya, dan membaca petunjuk pemanfaatan multimedia pembelajaran. Guru juga mempersiapkan materi untuk penjelasan awal sebelum siswa mengoperasikan multimedia pembelajaran interaktif, dan bagi sekolah lain yang berkeinginan untuk memanfaatkan media ini, sebaiknya sudah mempunyai lab komputer yang memadai untuk menunjang pemanfaatan media ini.

\section{PENUTUP}

Multimedia pembelajaran ini digunakan dalam pembelajaran sistem tata surya mata pelajaran Ilmu pengetahuan alam. Multimedia pembelajaran ini berisikan materi pembelajaran tentang sistem tata surya. Untuk memperjelas materi didukung dengan animasi, teks, gambar, video dan musik pengiring supaya menambah kemenarikan isinya dan mengurangi kejenuhan pada saat proses pembelajaran.

Hasil dari pengembangan ini berupa bentuk fisik yang akan disimpan dalam bentuk DVD (Digital Versatile Disc). Untuk menampilkannya dapat menggunakan DVDROM (Digital Versatile Disc Read Only Media) komputer. DVD sangat praktis dan mudah untuk dibawa, pembelajaran bisa 
dilakukan siswa selama tersedia perangkat komputer dan dapat juga dimanfaatkan secara individu maupun kelompok.

Multimedia pembelajaran ini divalidasikan kepada ahli media, ahli materi, dan diuji cobakan pada siswa/audiens. Multimedia pembelajaran Ilmu pengetahuan alam ini dinyatakan valid dan layak digunakan untuk proses pembelajaran Ilmu pengetahuan alam. Hal ini dibuktikan dengan hasil persentase validasi ahli media sebesar $88,4 \%$ berdasarkan kriteria, multimedia pembelajaran Ilmu pengetahuan alam termasuk kualifikasi valid, sedangkan hasil persentase validasi ahli materi sebesar $95 \%$ berdasarkan kriteria, multimedia pembelajaran Ilmu pengetahuan alam termasuk kualifikasi valid, hasil persentase uji coba audiens/ siswa satu lawan satu sebesar $96 \%$ berdasarkan kriteria, multimedia pembelajaran Ilmu pengetahuan alam termasuk kualifikasi valid, hasil persentase uji coba audiens/ siswa kelompok kecil sebesar $93 \%$ berdasarkan kriteria, multimedia pembelajaran Ilmu pengetahuan alam termasuk kualifikasi valid.

Hal ini menunjukkan bahwa multimedia pembelajaran valid digunakan sebagai media pembelajaran. Setelah dilakukan validasi kemudian dilanjutkan dengan tes hasil belajar pada saat uji coba lapangan untuk mengetahui kefektifan penggunaan multimedia pembelajaran.Untuk Tes Hasil Belajar, 35 siswa telah memenuhi KKM (Kriteria Ketuntasan Minimal) ilmu pengetahuan alam. Hasil persentase untuk tingkat keefektifan penggunaan, multimedia pembelajaran Ilmu pengetahuan alam ini mencapai 100\%. Dengan demikian dapat disimpulkan bahwa multimedia pembelajaran bisa dikatakan efektif, dan dapat digunakan dalam proses pembelajaran Ilmu pengetahuan alam. Berdasarkan kesimpulan di atas, SMPN 13 Malang sebaiknya segera menerapkan pembelajaran berbasis multimedia. Dengan adanya pengembangan multimedia pembelajaran ilmu pengetahuan alam dapat dijadikan bahan pertimbangan sebagai alternatif media yang digunakan untuk menunjang tercapainya tujuan pembelajaran, supaya dapat meningkatkan kenyamanan belajar siswa dan memberikan variasi untuk proses pembelajaran. Bagi sekolah lain yang berkeinginan untuk memanfaatkan media ini, sebaiknya sudah mempunyai lab computer yang memadai untuk menunjang pemanfaatan media ini.

\section{DAFTAR RUJUKAN}

Arikunto, S. 2002. Prosledur Penelitian (Suatu Pendekatan Praktik). Jakarta: Rineka Cipta.

Lee, W.W. \& Owen, D.L. 2004, Multimedia Based Instructional Design. San Fransisco: Pfeiffer.

Miarso, Y. 2005. Menyemai Benih Teknologi Pendidikan. Jakarta: Kencan 